\title{
Hematological features in children with systemic lupus erythematosus: are they more common than appreciated?
}

\author{
Muge Gokce ${ }^{1 *}$, Nesrin Besbas², Yelda Bilginer ${ }^{2}$, Mualla Cetin, Fatma Gumruk', Seza Ozen² \\ From 18th Pediatric Rheumatology European Society (PReS) Congress \\ Bruges, Belgium. 14-18 September 2011
}

\begin{abstract}
Aim
Hematological involvement is an important element of morbidity in systemic lupus erythematosus (SLE). In this retrospective study, we describe the hematological features that were observed in children with SLE in our pediatric center.
\end{abstract}

\section{Methods}

We evaluated the hematological findings of 40 children (33 female) with SLE diagnosed and followed at the Pediatric Rheumatology Division of Hacettepe University, Turkey.

\section{Results}

Median age at presentation was 12 years. The most common hematological finding was anemia $(n=27)$. Of these, Coombs test was positive in nineteen (70.3\%). Leukopenia, neutropenia and thrombocytopenia were detected in $32.5 \%(\mathrm{n}=13), 17.5 \%(\mathrm{n}=7)$ and $32.5 \%$ $(\mathrm{n}=13)$, respectively.

Bone marrow aspiration was performed in fifteen (37.5\%) mainly to assess the pancytopenia. Secondary dysplastic changes in myeloid and erythroid lineage, increased histiocytes and erythroid lineage hyperactivity were common findings by bone marrow evaluation. Acute lymphoblastic leukemia was diagnosed in a girl nine months after an initial diagnosis of SLE. She had received corticosteroids and azothiopurine for SLE.

Evidence of hemophagocytosis was present in bone marrow smears of five patients, one of these patients had a resistant course of severe macrophage activating syndrome and was treated with HLH 2004 protocole

${ }^{1}$ Hacettepe Medical Faculty, Pediatric Hematology Division, Ankara, Turkey Full list of author information is available at the end of the article and plasmapheresis. She died of secondary infections and multiorgan failure.

Antiphospholipid and anticardiolipin antibodies were positive in 11 and 13 of the patients, retrospectively. Of these patients, four developed deep vein thrombosis, one cerebral sinus thrombosis and one presented with purpura fulminans.

\section{Conclusion}

Hematological should be carefully assessed and treated vigorously to prevent the morbidity and possible mortality.

Author details

${ }^{1}$ Hacettepe Medical Faculty, Pediatric Hematology Division, Ankara, Turkey.

${ }^{2}$ Hacettepe Medical Faculty, Pediatric Rheumatology Division, Ankara, Turkey.

Published: 14 September 2011

doi:10.1186/1546-0096-9-S1-P242

Cite this article as: Gokce et al:: Hematological features in children with systemic lupus erythematosus: are they more common than appreciated? Pediatric Rheumatology 2011 9(Suppl 1):P242.

Submit your next manuscript to BioMed Central and take full advantage of:

- Convenient online submission

- Thorough peer review

- No space constraints or color figure charges

- Immediate publication on acceptance

- Inclusion in PubMed, CAS, Scopus and Google Scholar

- Research which is freely available for redistribution 